\title{
Feeding preferences of adult and juvenile rabbitfish Siganus argenteus in relation to chemical defenses of tropical seaweeds
}

\author{
Valerie J. Paul, Stephen G. Nelson, Herling R. Sanger \\ University of Guam Marine Laboratory, UOG Station, Mangilao, Guam 96923, USA
}

\begin{abstract}
The role of algal secondary metabolites in determining feeding preferences of adult and juvenile rabbitfish Siganus argenteus was examined in outdoor tanks on Guam. Secondary metabolites could not explain the preferences of these herbivores, although the presence of secondary metabolites appeared to account for the low palatability of some seaweeds, such as Tydemania expeditionis and Microcoleus lyngbyaceus. Other species, including Desmia hornemanni and Halimeda discoidea, that contained secondary metabolites with feeding-deterrent properties were of medium preference. Further species that produced secondary metabolites, including Asparagopsis taxiformis, Caulerpa spp., Chlorodesmis fastigiata, Dictyota spp., and Liagora farinosa were rapidly eaten, and neither their extracts nor their isolated metabolites significantly deterred grazing. Responses to algal chemistry differed between adults and juveniles. Juvenile $S$. argenteus were not deterred by extracts of $T$. expeditionis, Halymenia durvillaei, $H$. discoidea, and Enhalus acoroides, or the isolated metabolites chlorodesmin and flexilin that deterred the adults. As regards morphological defenses, several calcified seaweeds were of medium preference for both adult and juvenile rabbitfish; however, none of the highpreference seaweeds were calcified, and calcification and toughness were associated with low feeding preference.
\end{abstract}

\section{INTRODUCTION}

Several recent reviews summarize evidence supporting the hypothesis that, in coral reef habitats, secondary metabolites produced by seaweeds can function as chemical defenses toward herbivores (Hay \& Fenical 1988, Van Alstyne \& Paul in press). The intense grazing activity of herbivores, especially fishes and sea urchins, on coral reefs has been extensively documented (Hay 1981a, b, 1984a, b, Littler et al. 1983, Hay \& Taylor 1985, Lewis 1985, 1986, Lewis \& Wainwright 1985 , Carpenter 1986, Foster 1987, Morrison 1988, Hay \& Fenical 1988). Thus, herbivory could be an important evolutionary pressure selecting for chemical and morphological defenses in tropical algae. Indeed, some of the hundreds of bioactive secondary metabolites isolated from tropical algae (Norris \& Fenical 1982, Faulkner 1984,1986 ) have been shown to function as effective chemical defenses against a variety of herbivores (Targett et al. 1986, Hay et al. 1987, 1988a, b, Paul 1987, Paul et al. 1987, in press, Wylie \& Paul 1988).

One way to begin to unravel the complex associa- tions between tropical herbivores and seaweeds is to compare the dietary preferences and responses to algal secondary metabolites of individual herbivore species (Targett et al. 1986, Hay et al. 1987, 1988c, Wylie \& Paul 1988). In this study, we examined the feeding preferences of the rabbitfish Siganus argenteus (Quoy \& Gaimard), a reef-dwelling herbivore common throughout the tropical western Pacific. Rabbitfish are important herbivores on Guam reefs particularly during episodic recruitment events that occur in April and May (Kami \& Ikehara 1976). In some years, S. argenteus and $S$. spinus recruit in such large numbers that they consume virtually all of the palatable seaweeds and seagrasses on the reef flats around Guam (Tsuda \& Bryan 1973, pers. obs). The role of algal secondary metabolites as defenses against grazing by these herbivores was the major focus of this investigation. We asked the following questions: (1) What are the seaweed preferences of juvenile and adult $S$. argenteus? (2) Do preferred seaweeds lack potential chemical and morphological defenses such as secondary metabolites, calcification, and/or toughness? (3) Do extracts and 
isolated metabolites from seaweeds that produce secondary metabolites function as feeding deterrents toward $S$. argenteus? (4) Do juvenile and adult $S$. argenteus show similar responses to algal extracts and secondary metabolites?

\section{METHODS}

Seaweeds and fish used in this study were collected from various reef habitats around Guam, including reef slopes, reef flats, and seagrass beds. Information on the seaweeds of Guam, including taxonomic descriptions and authorities, is presented by Tsuda \& Wray (1977). We selected species of seaweeds that were abundant enough to use in the preference trials and to provide sufficient material for chemical extractions. Seaweeds were maintained outdoors in large, flowing seawater tanks and were used in preference trials within $24 \mathrm{~h}$ of collection. Damaged or discolored plants were not used in the assays. Juvenile ( 6 to $8 \mathrm{~cm}$ TL) and adult (20 to $23 \mathrm{~cm}$ TL) Siganus argenteus were collected by dip net or cast net and maintained on food pellets and the seaweed Enteromorpha in outdoor flow-through tanks for periods ranging from several days to weeks prior to the study.

Feeding preference assays. Seaweed preferences of adult and juvenile Siganus argenteus were determined by providing an array of seaweeds to replicate fish or small groups of fish held in separate divisions within large, outdoor, flow-through tanks. Adults were tested individually in 12 large, $1 \mathrm{~m} \times 1 \mathrm{~m} \times 1.5 \mathrm{~m}$, black, $1 / 4^{\prime \prime}$ $(6 \mathrm{~mm})$ plastic mesh compartments within two $5000 \mathrm{l}$ tanks. Juveniles were tested in groups of 3 to 5 fish held in $16,0.5 \mathrm{~m} \times 0.5 \mathrm{~m} \times 0.5 \mathrm{~m}$, black, plastic mesh compartments in a $2000 \mathrm{l}$ tank. The holding compartments physically and visually separated the fish and served as replicates for these assays. Juveniles were tested in groups rather than individually because individuals did not consume much alga per unit time.

Susceptibility of the various seaweeds to grazing was examined by inserting small, ca $6 \mathrm{~cm}$ long, equalsized pieces, at $5 \mathrm{~cm}$ intervals, into a $0.5 \mathrm{~m}$ length of 3 . strand polypropylene line. Lines were suspended $0.1 \mathrm{~m}$ above the bottom from PVC racks. Pieces of seaweed appearing similar in size were used so that all species should be equally apparent and available to the fish. Pieces of 5 to 14 seaweeds were inserted into the lines and offered to fish for ca $1 \mathrm{~h}$. By this time, there was usually a clear distinction between the most and least susceptible plants. Similar methods have been used in seaweed susceptibility trials in field assays (Hay 1984a, Paul \& Hay 1986). The thalli were weighed before and after the assays to determine the amount of each seaweed consumed. Seaweeds were spun for 20 revolutions in a lettuce spinner and blotted dry on paper towels before weighing. The amount of each seaweed eaten was calculated for each replicate fish (adults) or group of fish (juveniles). Results were reported as the mean wet mass and percentage of each seaweed consumed. Because of the short duration of the assays, changes in weights of the seaweeds due to effects other than herbivory were assumed to be negligible.

Seaweeds used in the preference assays included the fleshy green seaweeds Bryopsis pennata, Chlorodesmis fastigiata, Cladophoropsis membranacea, Enteromorpha clathrata; the erect, uncalcified green seaweeds Avrainvillea obscura, Caulerpa racemosa, Valonia fastigiata; the calcified green seaweeds Halimeda spp., Tydemania fastigiata; the erect brown alga Dictyota bartayresii; the erect, lightly calcified brown alga Padina tenuis; the tough, leathery brown algae Sargassum cristaefolium, Turbinaria ornata; the erect, uncalcified red algae Asparagopsis taxiformis, Desmia hornemanni, Halymenia durvillaei; the erect, calcified red algae Galaxaura marginata, Liagora farinosa; the seagrasses Enhalus acoroides, Halodule uninervis; and the blue-greens Calothrix crustacea and Microcoleus lyngbyaceus. Most of these same seaweeds were extracted and used later in the chemical feeding deterrent assays.

Five different preference experiments were conducted for the adult rabbitfish, and 3 experiments were conducted for the juveniles. In most cases, the same fish were used for the different experiments. Each experiment used a different group of seaweeds, although some species were repeated in different experiments. Based on the results, the seaweeds were categorized as either low preference ( 0 to $20 \%$ eaten), medium preference (21 to $60 \%$ eaten), or high preference (> $60 \%$ eaten). Relationships between the number of seaweeds in each of the 3 preference categories and the presence of both secondary chemistry and calcification were examined by Contingency Table Analysis with the G-test.

Chemical analyses. Seaweeds were blotted dry, cleaned of epiphytes, and extracted by homogenizing them in a blender with a $1: 1$ mixture of dichloromethane and methanol. The extracts were filtered, and the solvents were evaporated under reduced pressure with a rotary evaporator to yield a viscous oil

Thin layer chromatographic analysis (TLC) (Norris \& Fenical 1985) and proton nuclear magnetic resonance (NMR) spectroscopy were used to detect the presence or absence of secondary metabolites in the algae (Paul \& Hay 1986). TLC plates were developed in 2 solvent systems, $100 \%$ dichloromethane and $100 \%$ diethyl ether, to screen for nonpolar and more polar metabolites. The plates were viewed under an 
ultraviolet lamp to observe activity indicative of unusual metabolites. The plates were then sprayed with $50 \%$ sulfuric acid and heated so that unusual color reactions indicating the presence of secondary metabolites could be observed.

Because TLC tells little about the chemical structures of compounds in the extracts unless the compounds can be related to known standards, we also examined the extracts by proton nuclear magnetic resonance spectroscopy (NMR). Known compounds can be readily detected and identified by NMR spectroscopy.

Individual secondary metabolites were isolated by silica gel column chromatography followed by high performance liquid chromatography (HPLC) (Paul \& Fenical 1985, 1986).

Chemical feeding deterrent assays. Similar methods have been used in evaluating the feeding deterrence of crude extracts and isolated metabolites toward other herbivorous fishes (Wylie \& Paul 1988, Paul et al. in press). Small pieces of a preferred alga Enteromorpha clathrata were pressed and blotted dry on paper towels and then coated with a solution of either the extract or the isolated metabolite dissolved in diethyl ether. The final concentrations on treated $E$. clathrata were 4 to $5 \%$ of the estimated dry mass in trials with extracts and ca $1 \%$ of the estimated dry mass in trials with pure metabolites. Dry mass of the wet E. clathrata was estimated by a previously calculated wet mass: dry mass ratio of 4.5.1. The concentrations approximated natural concentrations of most seaweed extracts which were determined during extraction. Organic extracts from uncalcified algae ranged from 5 to $8 \%$ of the dry mass of the plants, and extracts from calcified algae were 3 to $6 \%$ of the dry mass of the plants. Control pieces of E. clathrata were coated with diethyl ether only. Cladophoropsis membranacea, another preferred alga based on our studies, was used for approximately half of the assays with juvenile rabbitfish because Enteromorpha became unavailable during June and July 1988 when these assays were conducted.

For these assays, the fish were placed into separate compartments in flow-through tanks as described for the feeding preference assays. Adults were tested as individuals ( $\mathrm{n}=8$ to 11 replicates), and juveniles were tested in separate groups of 3 to 5 individuals ( $n=9$ to 15 replicate groups). In assays with seaweed extracts, pieces of preferred algae weighed ca $5 \mathrm{~g}(\mathrm{SD}=0.05 \mathrm{~g}$ ) for both control and treated pieces, while smaller, ca $2 \mathrm{~g}$ pieces were used both for testing isolated secondary metabolites toward the adults and in all of the assays with juveniles. For each assay, one piece of treated and one piece of control Enteromorpha clathrata were inserted at opposite ends of a strand of polypropylene line and offered to the rabbitfish for about $15 \mathrm{~min}$. Lines were suspended $0.1 \mathrm{~m}$ above the bottom from PVC racks as before. We observed the fish during the assays and removed the lines before all of either the control or treated algae had been consumed. The rabbitfish always attacked both treated and control algae initially and did not appear to detect any extract in the water around the algae. If the extract was deterrent, we often observed the fish biting and then rejecting the treated thalli, then the fish would rapidly consume the control algae before eating the treated algae. If the lines were left in the tanks too long, both of the E. clathrata pieces, treated and control, were often eaten. These replicates were excluded from the analyses. E. clathrata pieces were weighed before and after the assays. The pieces were carefully pressed and blotted dry with paper towels prior to weighing to determine the amount of control and treated algae consumed.

Both the extracts and the pure metabolites are lipophilic and adhere to the surfaces of the algae after the ether evaporates. McConnell et al. (1982), Hay et al. (1987), and Paul (1987) used similar methods and found that the compounds remained on the coated algae for at least 4 to $8 \mathrm{~h}$. The duration of our assays was short (15 to $30 \mathrm{~min}$ ), thus we assumed that loss of the compounds to seawater was negligible. In addition, we ran a TLC of the extract remaining on the surface of the algae after the assays to be sure that the secondary metabolites were still present and had not decomposed

We tested each algal extract twice toward the same adult fish, randomizing the order in which the extracts were tested. We designated the 2 tests with the same extract as Trial 1 and Trial 2. Extracts were tested toward juvenile Siganus argenteus only once. All purified metabolites were also tested only once toward both adults and juveniles. The same fish were used throughout the assays. One assay was conducted per day, and fish were fed an abundance of algae and pelleted food between assays.

Assay results for adult Siganus argenteus were analyzed by a 3-way analysis of variance (ANOVA). The 3 factors used in the analyses were Treatment (control or treated), Trial, and Individual fish. A mixed model design without replication was used with Treatment and Trial as fixed factors and Individual fish as a random factor. For the assays with juveniles and the assays with isolated metabolites, we used a matchedpairs $t$-test to analyze the data. All statistical tests used the amounts $(\mathrm{g})$ of control and treated algae eaten for the analyses. The statistical analyses were conducted with BMDP statistical programs available from the Health Science Computing Facility of the University of California at Los Angeles. Program BMDP 3D was used for the matched pairs $t$-test; BMDP $8 \mathrm{~V}$ was used for the mixed model 3-way ANOVA (Dixon 1985) 


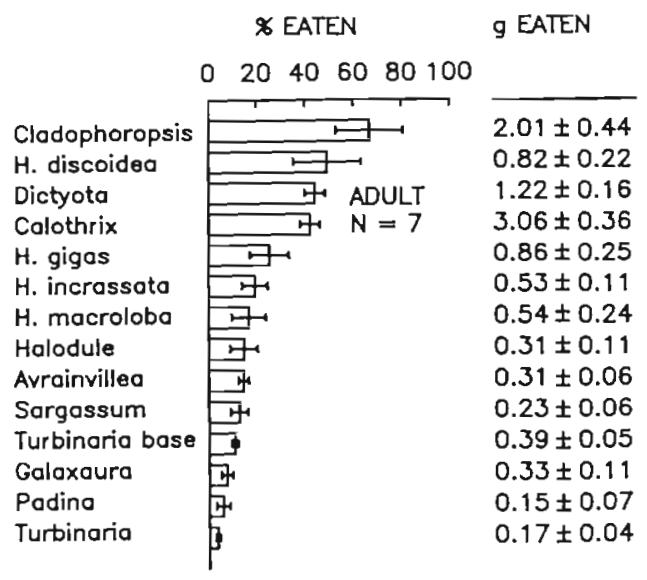

\begin{tabular}{|c|c|c|c|}
\hline & \& EAT & & g EATEN \\
\hline & $0 \quad 2040$ & $60 \quad 80100$ & \\
\hline & 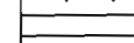 & H & $5.07 \pm 0.74$ \\
\hline Chlorodesmis & E & 7 & $4.54 \pm 0.53$ \\
\hline Asparagopsis & $\Rightarrow$ & ADULT & $2.65 \pm 0.17$ \\
\hline Goloxaura & 7 & $N=7$ & $1.27 \pm 0.34$ \\
\hline Bryopsis & 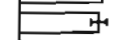 & & $1.71 \pm 0.20$ \\
\hline Podino & $\exists$ & & $0.39 \pm 0.06$ \\
\hline H. discoidea & F & & $0.34 \pm 0.08$ \\
\hline
\end{tabular}

$\begin{array}{llllll}0 & 20 & 40 & 60 & 80 & 100\end{array}$

Enteromorpha
Chlorodesmis
Liagora
Desmia
Valonia
H. discoidea
Tydemania
Galaxaura
Halymenia

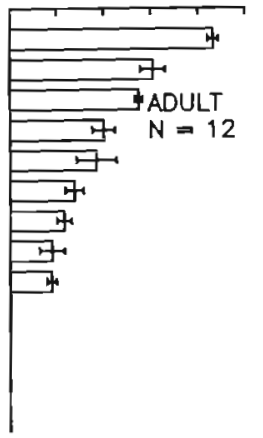

$020 \quad 40 \quad 60 \quad 80100$

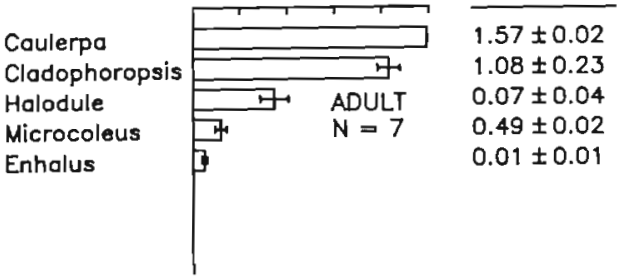

$02040 \quad 60 \quad 80100$

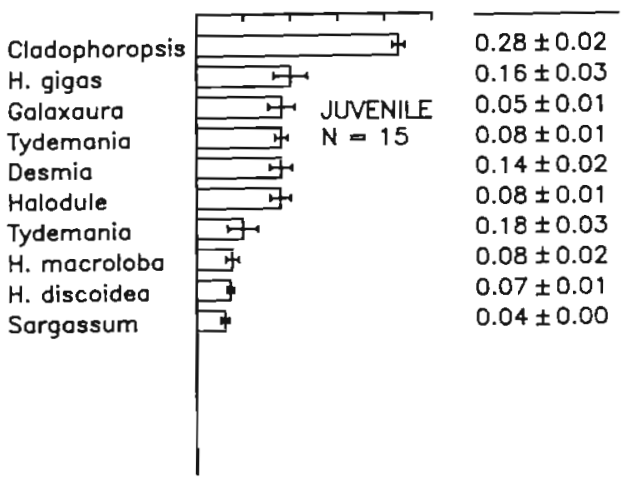

$4.37 \pm 0.12$

$5.52 \pm 0.48$

$6.49 \pm 0.30$

$2.45 \pm 0.30$

$6.64 \pm 1.47$

$3.35 \pm 0.58$

$2.11 \pm 0.28$

$0.93 \pm 0.30$

$1.11 \pm 0.12$
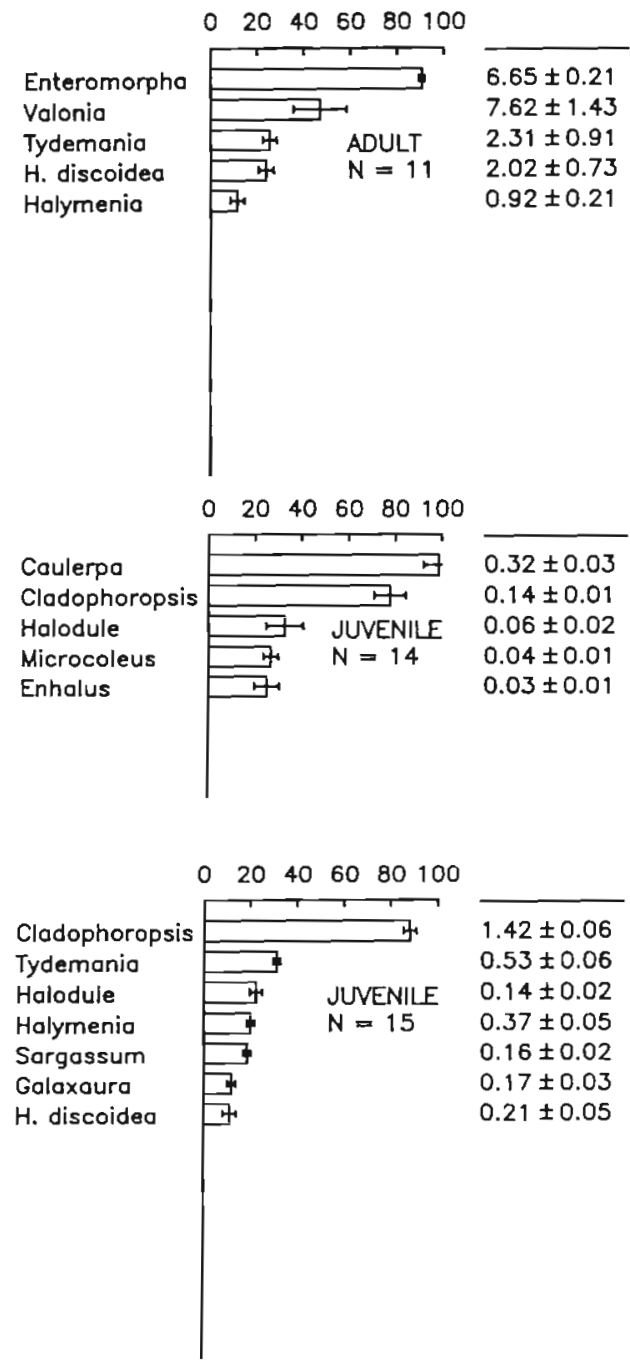

Fig. 1. Siganus argenteus. Feeding preferences of adults and juveniles. Bars represent $\%$ of each seaweed eaten (X $\pm \mathrm{SE}$ ). $\mathrm{N}$ number of repilcates with individual fish (adults) or groups of fish (juveniles). Numbers beside each bar are the amount ( $g$ ) of seaweed eaten $\pm 1 \mathrm{SE}$. Each histogram represents a separate experiment conducted on a different day 


\section{RESULTS}

\section{Feeding preferences}

Fig. 1 and Table 1 present the seaweed preferences of the adult and juvenile Siganus argenteus. Fig. 1 presents the data as both the percentage and amount (g) of each seaweed consumed. Generally, the seaweed preferences were similar whether ranked by percentage or amount consumed, and the groupings into high, medium, or low preference did not vary. However, for a few species such as Liagora farinosa, Calothrix crustacea, and Valonia fastigiata, rankings based on the amount consumed differed from those based on the percent consumed. This discrepancy is an artifact of selecting pieces of seaweeds of comparable appearance rather than of comparable weight. L. farinosa and C. crustacea were ranked as medium preference based on percentage eaten (Table 1). Seaweed preferences were similar for adult and juvenile $S$. argenteus, and there was no significant relationship between the presence of secondary chemistry and feeding preference for either adult or juvenile $S$. argenteus (Table 1). Morphological defenses (calcification and/or toughness) were more closely associated with feeding preference. Seaweeds with tough or calcified morphologies tended to be of low preference to adult $S$. argenteus and were significantly associated with low feeding preference by juveniles.

For the adults, 5 of 7 low-preference seaweeds, 8 of 10 medium-preference seaweeds, and 2 of 5 highpreference seaweeds produced secondary metabolites $(3 \times 2$ Contingency Table Analysis, $G=2.41, p>$ 0.25 : Table 1). Also, 4 of 4 species of low-preference seaweeds, 5 of 11 species of medium-preference seaweeds, and none of the 5 high-preference seaweeds were calcified or tough $(\mathrm{G}=5.50,0.1>\mathrm{p}>0.05$; Table 1).

Table 1. Siganus argenteus. Feeding preferences of adults and juveniles. Only major secondary metabolites are listed under defenses. Structures of the major metabolites are shown in Fig. 2. Symbols are: $C$, calcified seaweed; $T$, seaweed with a tough or leathery morphology; -, no secondary metabolites detected; ?, presence of secondary metabolites uncertain, either results were not clear or seaweeds were not examined for presence of secondary metabolites. Low preference (L) $=0$ to $20 \%$ eaten; medium preference $(M)=21$ to $60 \%$ eaten; high preference $(H)>60 \%$ eaten

\begin{tabular}{|c|c|c|c|}
\hline Alga & Defenses & $\begin{array}{l}\text { Adult } \\
\text { preference }\end{array}$ & $\begin{array}{l}\text { Juvenile } \\
\text { preference }\end{array}$ \\
\hline \multicolumn{4}{|l|}{ Cyanophyta } \\
\hline Calothrix crustacea & $?$ & $\mathrm{M}$ & \\
\hline Microcoleus lyngbyaceus & Malyngamides & $\mathrm{L}$ & M \\
\hline \multicolumn{4}{|l|}{ Chlorophyta } \\
\hline Avrainvillea obscura & Avrainvilleol & $\mathrm{L}$ & \\
\hline Bryopsis pennata & Polar lipids & M & \\
\hline Caulerpa racemosa & Caulerpenyne & $\mathrm{H}$ & $\mathrm{H}$ \\
\hline Chlorodesmis fastigiata & Chlorodesmin & $\mathrm{H}$ & \\
\hline Cladophoropsis membranacea & - & $\mathrm{H}$ & $\mathrm{H}$ \\
\hline Enteromorpha clathrata & - & $\mathrm{H}$ & \\
\hline Halimeda discoidea & C, tetraacetate and halimedatrial & $\mathrm{M}$ & $\mathrm{L}$ \\
\hline Halimeda gigas & C, pentaacetate & M & $\mathrm{M}$ \\
\hline Halimeda incrassata & C, tetraacetate & $\mathrm{L}$ & \\
\hline Halimeda macroloba & C, tetraacetate & $\mathrm{L}$ & $\mathrm{L}$ \\
\hline Tydemania expeditionis & C, alcohol & M & $\mathrm{M}$ \\
\hline Valonia fastigiata & - & $\mathrm{H}$ & \\
\hline \multicolumn{4}{|l|}{ Phaeophyta } \\
\hline Dictyota bartayresii & Dictyols & M & \\
\hline Padina tenuis & $C_{1}-$ & $\mathrm{L}$ & \\
\hline Sargassum cristaefolium & $T_{1}-$ & & L \\
\hline Turbinaria ornata & $\mathrm{T}_{1}-$ & L & \\
\hline \multicolumn{4}{|l|}{ Rhodophyta } \\
\hline Asparagopsis taxiformis & Halogenated ketones and acetones & M & \\
\hline Desmia hornemanni & Halogenated monoterpenes & M & M \\
\hline Galaxaura marginata & $C_{1}-$ & $M$ & M \\
\hline Halymenia durvillaei & Polar lipids & $\mathrm{L}$ & $M$ \\
\hline Liagora farinosa & C, acetogenins & M & \\
\hline \multicolumn{4}{|l|}{ Anthophyta (seagrasses) } \\
\hline Enhalus acoroides & $?$ & $\mathrm{~L}$ & $M$ \\
\hline Halodule uninervis & - & M & M \\
\hline
\end{tabular}


For the results of experiments with juveniles, medium- and high-preference seaweeds were combined for analyses because only 2 species were of high preference. For these assays, 2 of 3 species of lowpreference seaweeds, and 5 of 9 species of medium-to high-preference seaweeds, produced secondary metabolites $(2 \times 2$ Contingency Table Analysis, $\mathrm{G}=$ $0.11, p>0.5$; Table 1). Of the low-preference seaweeds, all 3 species were calcified or tough, but only 3 of 10 species of the medium- to high-preference seaweeds were calcified or tough $(\mathrm{G}=5.73, \mathrm{p}>0.025$; Table 1$)$.

\section{Chemical feeding deterrents}

Table 2 shows the results of algal extract assays with adult Siganus argenteus. Extracts of Desmia hornemanni, Enhalus acoroides, Halymenia durvillaei, Halimeda discoidea, Microcoleus lyngbyaceus, and Tydemania expeditionis were all significantly deterrent $(p<0.05)$ toward adult $S$. argenteus. Extracts of $D$. hornemanni and $M$. lyngbyaceus that were significant deterrents overall were more strongly deterrent in one trial than in the other, and we observed significant effects attributed to the Trial factor as well as Treatment-Trial interactions in the ANOVA tests (Table 2). Many extracts showed significant Trial effects which indicated that, overall, different amounts of Enteromorpha clathrata were eaten in different trials. The trial effects are not important since the durations of the assays were approximate. Several extracts showed Treatment-Trial interactions which may have resulted from variation in algal chemistry among collections, or from differing physiological states, such as hunger, of the fish between trials. However, we always examined the extracts by TLC to ensure consistency among collections and did not use extracts that showed any evidence of chemical decomposition, so these potential sources of variation were eliminated.

The extracts of Desmia hornemannii and Microcoleus lyngbyaceous were deterrent toward juvenile Siganus argenteus as well as toward adults (Table 3 ). Thalli of $D$. hornemannii were of medium preference for both adult and juvenile $S$ argenteus (Fig. 1; Table 1), although the extracts and isolated metabolites were strong feeding deterrents.

Extracts of the preferred alga Chlorodesmis fastigiata did not deter either adults or juveniles (Tables 2 and 3 ). Extracts of Halymenia durvillaei, Halimeda discoidea. Tydemania expeditionis, and the seagrass Enhalus acoroides were deterrent toward adult $S$. argenteus but not toward juveniles. We do not know what the chemical feeding deterrents are present in $H$. durvillaei or $E$. acoroides, and we are currently examining the extracts for secondary metabolites. Halophila minor and other seagrasses from Guam have been reported to contain phenolic acids (Zapata \& McMillan 1979).

Of the pure secondary metabolites isolated from the seaweeds used in this study, the only metabolite that was an effective deterrent toward both adults and juveniles was ochtodene, isolated from Desmia hornemanni (Table 4). A nonpolar mixture of ochtodene and acyclic halogenated monoterpenes was the only other isolate deterrent toward the juveniles, but the deterrence may have been due to ochtodene alone. Adults were also significantly deterred by chlorodesmin (although the crude algal extract was nondeterrent), by the structurally related alcohol from $T$. expeditionis, and by flexilin. None of the other metabolites were significantly deterrent.

\section{DISCUSSION}

Results indicate that some seaweed secondary metabolites are effective feeding deterrents toward the rabbitfish Siganus argenteus on Guam; however, there is no clear relationship between secondary metabolite production by seaweeds and low susceptibility to $S$. argenteus. Extracts from some of the low- or mediumpreference algae producing secondary metabolites that functioned as feeding deterrents included: Desmia hornemanni, which produces halogenated monoterpenoids (Burreson et al. 1975b, c) including ochtodene (Paul et al. 1987); Halimeda discoidea, which produces diterpenoids including halimedatetraacetate and halimedatrial (Paul \& Fenical 1986, Paul \& Van Alstyne 1988); Microcoleus lyngbyaceus, which produces nitrogenous metabolites malyngamides A and B (Cardellina et al. 1978, 1979), and Tydemania expeditionis, which produces acyclic diterpenoids related to chlorodesmin (Paul \& Fenical 1985).

Interestingly, several algal species that produce high concentrations of secondary metabolites were eaten by the rabbitfish, and neither their extracts nor their isolated metabolites significantly deterred feeding. These included: Asparagopsis taxiformis, which produces halogenated ketones and acetones (Burreson et al. 1975a, McConnell \& Fenical 1977, Woolard et al. 1979); Caulerpa racemosa which produces the metabolites caulerpin (Maiti et al. 1978) and caulerpenyne (Amico et al. 1978); Dictyota bartayresii which produces dictyol diterpenoids including pachydictyol A (Faulkner 1984, Paul \& Fenical unpubl.); Liagora farinosa, which produces acetylene-containing acetogenins (Paul \& Fenical 1980), and Chlorodesmis fastigiata, which produces chlorodesmin and related acyclic diterpenoids (Wells \& Barrow 1979, Paul \& Fenical 1985). Chlorodesmin deterred adult but not juvenile rabbitfish. Several nondeterrent secondary metabolites were structurally 
Table 2. Siganus argenteus. Results of chemical feeding deterrent trials with adult rabbitfish. All extracts were tested at 4 to $5 \%$ dry weight coated on Enteromorpha clathrata. Data were analyzed by a mixed-model 3-way ANOVA. Treatment and Trial are fixed factors, Fish is a random factor

\begin{tabular}{|c|c|c|c|c|c|c|}
\hline \multirow[t]{2}{*}{ Species } & \multirow[t]{2}{*}{ Trial } & \multirow[t]{2}{*}{$\mathrm{N}$} & \multicolumn{2}{|c|}{ Mean $\%$ eaten $\pm \mathrm{SE}$} & \multicolumn{2}{|c|}{ p-values } \\
\hline & & & Control & Treated & Treatment & Trial \\
\hline \multicolumn{7}{|l|}{ Deterrents } \\
\hline \multirow[t]{3}{*}{ Desmia hornemanni } & & & & & 0.000 & 0.000 \\
\hline & 1 & 11 & $72.7 \pm 3.3$ & $24.0 \pm 3.2$ & \multirow{2}{*}{\multicolumn{2}{|c|}{$\begin{array}{c}\text { Treatment-Trial interaction } \\
\qquad \mathrm{p}=0.001\end{array}$}} \\
\hline & 2 & 11 & $79.5 \pm 3.0$ & $69.0 \pm 3.7$ & & \\
\hline \multirow[t]{3}{*}{ Enhalus acoroides } & & & & & \multirow[t]{3}{*}{0.001} & \multirow[t]{3}{*}{0.004} \\
\hline & 1 & 11 & $62.4 \pm 4.0$ & $34.9 \pm 3.5$ & & \\
\hline & 2 & 11 & $45.0 \pm 5.3$ & $19.3 \pm 3.9$ & & \\
\hline \multirow[t]{3}{*}{ Halimeda discoidea } & & & & & \multirow[t]{3}{*}{0.033} & \multirow[t]{3}{*}{0.000} \\
\hline & 1 & 11 & $51.8 \pm 5.1$ & $30.8 \pm 5.6$ & & \\
\hline & 2 & 11 & $77.5 \pm 4.3$ & $72.1 \pm 2.1$ & & \\
\hline \multirow[t]{3}{*}{ Halymenia durvillaei } & & & & & \multirow[t]{3}{*}{0.044} & \multirow[t]{3}{*}{0.000} \\
\hline & 1 & 11 & $53.2 \pm 7.2$ & $42.1 \pm 2.6$ & & \\
\hline & 2 & 11 & $87.2 \pm 3.9$ & $78.6 \pm 3.4$ & & \\
\hline \multirow[t]{3}{*}{ Microcoleus lyngbyaceus } & & & & & \multirow{3}{*}{\multicolumn{2}{|c|}{$\begin{array}{l}0.021 \quad 0.000 \\
\text { Treatment-Trial interaction } \\
\quad p=0.007\end{array}$}} \\
\hline & 1 & 11 & $65.8 \pm 2.8$ & $46.8 \pm 4.6$ & & \\
\hline & 2 & 11 & $77.3 \pm 1.9$ & $77.6 \pm 2.0$ & & \\
\hline \multirow[t]{3}{*}{ Tydemania expeditionis } & & & & & 0.038 & 0.580 \\
\hline & 1 & 11 & $29.4 \pm 5.1$ & $23.3 \pm 4.3$ & & \\
\hline & 2 & 11 & $37.3 \pm 3.9$ & $19.8 \pm 4.4$ & & \\
\hline Nondeterrents & & & & & & \\
\hline Asparagopsis taxiformis & & & & & 0.051 & 0.000 \\
\hline & 1 & 8 & $59.6 \pm 3.9$ & $48.0 \pm 9.2$ & Treatmen & eraction \\
\hline & 2 & 8 & $42.9 \pm 5.1$ & $62.1 \pm 2.8$ & & \\
\hline Avrainvillea obscura & & & & & 0.610 & 0.000 \\
\hline & 1 & 10 & $86.2 \pm 2.8$ & $79.0 \pm 3.2$ & & \\
\hline & 2 & 10 & $42.2 \pm 5.2$ & $54.2 \pm 5.6$ & & \\
\hline Bryopsis pennata & & & & & 0.387 & 0.053 \\
\hline & 1 & 10 & $48.1 \pm 8.2$ & $46.7 \pm 7.3$ & & \\
\hline & 2 & 10 & $39.3 \pm 4.5$ & $30.4 \pm 3.0$ & & \\
\hline Caulerpa racemosa & & & & & 0.978 & 0.000 \\
\hline & 1 & 11 & $79.4 \pm 3.6$ & $65.6 \pm 4.5$ & Treatmen & eraction \\
\hline & 2 & 11 & $19.8 \pm 2.3$ & $32.9 \pm 5.6$ & & \\
\hline Chlorodesmis fastigiata & & & & & 0.388 & 0.077 \\
\hline & 1 & 11 & $54.8 \pm 5.1$ & $48.5 \pm 6.0$ & & \\
\hline & 2 & 11 & $31.5 \pm 6.2$ & $44.5 \pm 6.2$ & & \\
\hline Dictyota bartayresii & & & & & 0.244 & 0.000 \\
\hline & 1 & 10 & $75.4 \pm 2.0$ & $79.0 \pm 1.1$ & Treatmen & eraction \\
\hline & 2 & 10 & $39.0 \pm 10.3$ & $18.1 \pm 5.7$ & & \\
\hline Halimeda macroloba & & & & & 0.353 & 0.000 \\
\hline & 1 & 11 & $88.6 \pm 1.8$ & $86.9 \pm 1.6$ & & \\
\hline & 2 & 11 & $66.1 \pm 2.2$ & $61.3 \pm 3.8$ & & \\
\hline Halophila minor & & & & & 0.260 & 0.000 \\
\hline & 1 & 11 & $63.4 \pm 3.9$ & $57.3 \pm 4.9$ & & \\
\hline & 2 & 11 & $47.4 \pm 6.7$ & $38.3 \pm 8.5$ & & \\
\hline Liagora farinosa & & & & & 0.148 & 0.024 \\
\hline & 1 & 11 & $49.3 \pm 7.5$ & $50.4 \pm 5.6$ & & \\
\hline & 2 & 11 & $71.9 \pm 5.6$ & $52.6 \pm 4.5$ & & \\
\hline Valonia fastigiata & & & & & 0.694 & 0.061 \\
\hline & 1 & 11 & $62.9 \pm 4.8$ & $59.9 \pm 3.4$ & & \\
\hline & 2 & 11 & $67.2 \pm 4.3$ & $65.6 \pm 3.7$ & & \\
\hline
\end{tabular}


Table 3. Siganus argentelus. Results of chemical feeding deterrent trials with juvenile rabbitfish. All extracts were tested at 4 to $5 \%$ dry weight, coated on Enteromorpha clathrata $(=E)$ or Cladophoropsis membranacea $(=C)$. N: number of cages with different fish; p-values were determined by the paired t-test (2-tailed). Significant feeding deterrent at $\mathrm{p}<0.05$

\begin{tabular}{|lrcccc}
\hline Algal extract & N & Alga used & \multicolumn{2}{c}{$\begin{array}{c}\text { Mean } \% \text { eaten } \pm \text { SE } \\
\text { Control }\end{array}$} & p-value \\
\hline Asparagopsis taxiformis & 15 & $\mathrm{C}$ & $54.77 \pm 3.74$ & $56.06 \pm 4.59$ & 0.741 \\
Avrainvillea abscura & 14 & $\mathrm{C}$ & $54.80 \pm 3.55$ & $49.71 \pm 3.53$ & 0.196 \\
Bryopsis pennata & 14 & $\mathrm{C}$ & $71.60 \pm 2.58$ & $66.29 \pm 3.44$ & 0.174 \\
Caulerpa racemosa & 14 & $\mathrm{E}$ & $56.47 \pm 2.52$ & $55.76 \pm 4.22$ & 0.903 \\
Chlorodesmis fastigiata & 15 & $\mathrm{C}$ & $44.88 \pm 3.55$ & $51.27 \pm 3.37$ & 0.091 \\
Desmia hornemannii & 14 & $\mathrm{E}$ & $72.02 \pm 2.18$ & $45.00 \pm 2.40$ & $0.000^{*}$ \\
Dictyota bartayresii & 15 & $\mathrm{C}$ & $57.50 \pm 3.63$ & $57.19 \pm 3.21$ & 0.639 \\
D. cervicornis & 14 & $\mathrm{E}$ & $69.93 \pm 5.34$ & $67.89 \pm 7.36$ & 0.724 \\
Enhalus acoroides & 14 & $\mathrm{C}$ & $73.10 \pm 1.97$ & $68.84 \pm 2.82$ & 0.261 \\
Halimeda discoidea & 14 & $\mathrm{E}$ & $70.21 \pm 2.61$ & $67.70 \pm 3.65$ & 0.492 \\
Halimeda macroloba & 14 & $\mathrm{E}$ & $59.79 \pm 2.72$ & $62.63 \pm 2.56$ & 0.473 \\
Halophila minor & 9 & $\mathrm{C}$ & $66.96 \pm 5.10$ & $71.04 \pm 3.69$ & 0.280 \\
Halymenia durvillaei & 14 & $\mathrm{C}$ & $70.39 \pm 3.73$ & $73.70 \pm 2.74$ & 0.146 \\
Microcoleus lyngbyaceus & 15 & $\mathrm{C}$ & $52.77 \pm 2.64$ & $37.16 \pm 2.56$ & 0.001 \\
Tydemania expeditionis & 14 & $\mathrm{E}$ & $62.99 \pm 3.94$ & $66.73 \pm 2.79$ & 0.446 \\
Valonia fastigiata & 14 & $\mathrm{C}$ & $69.03 \pm 3.85$ & $66.80 \pm 3.42$ & 0.564 \\
\hline
\end{tabular}

similar to deterrent metabolites (Fig. 2), therefore it is difficult to determine whether a compound will function as a feeding deterrent based on its chemical structure. For example, linear terpenoids from green algae including chlorodesmin, Tydemania alcohol, and flexilin were deterrent while other structurally-related green algal terpenoids including caulerpenyne and udoteal were not (Fig. 2).

While fish only avoided the treated Enteromorpha clathrata after biting it, defended whole seaweeds were often avoided in feeding preference assays. It appears that fish initially perceive deterrents via their sense of taste but then learn to recognize chemically defended seaweeds visually.
Our results indicate that morphological defenses such as calcification and toughness were associated with low susceptibility to grazing by Siganus argenteus, especially for juveniles. Juveniles appeared to be more susceptible to seaweed morphology and less susceptible to secondary chemistry than the adults. Some seaweeds which produced both calcification and secondary metabolites, such as Halimeda spp. and Tydemania expeditionis, were avoided by both adult and juvenile rabbitfish. The importance of combined calcification and chemical defenses in tropical seaweeds has been discussed previously (Hay 1984a, Paul \& Hay 1986, Paul \& Fenical 1986).

Our results are consistent with published studies on

Table 4. Siganus argenteus. Results of chemical feeding deterrent trals with rabbitfish. All isolated metabolites were tested at $1 \%$ dry weight coated on Enteromorpha clathrata. N: number of trials with different fish; p-values determined by the paired t-test (2-

tailed). 'Significant feeding deterrent. 'Significant feeding attractant at $p<0.05$. Blanks indicate compounds not tested

\begin{tabular}{|c|c|c|c|c|c|c|c|c|}
\hline \multirow[t]{3}{*}{ Metabolite } & \multicolumn{4}{|c|}{ Juveniles } & \multicolumn{4}{|c|}{ Adults } \\
\hline & \multirow[t]{2}{*}{$N$} & \multicolumn{2}{|c|}{ Mean $\%$ eaten \pm SE } & \multirow[t]{2}{*}{ p-value } & \multirow[t]{2}{*}{$N$} & \multicolumn{2}{|c|}{ Mean \% eaten $\pm \mathrm{SE}$} & \multirow{2}{*}{$p$-value } \\
\hline & & Control & Treated & & & Control & Treated & \\
\hline Avrainvilleol & & & & & 1.2 & $69.97 \pm 4.24$ & $68.97 \pm 5.16$ & 0.757 \\
\hline Bryopsin & & & & & 11 & $65.39 \pm 8.03$ & $71.31 \pm 7.93$ & 0.660 \\
\hline Caulerpenyne & 14 & $75.46 \pm 1.67$ & $70.44 \pm 2.07$ & 0.113 & 12 & $57.00 \pm 6.62$ & $69.54 \pm 3.93$ & 0.215 \\
\hline Caulerpin & & & & & 12 & $40.96 \pm 4.68$ & $38.41 \pm 6.47$ & 0.761 \\
\hline Chlorodesmin & 14 & $86.79 \pm 1.11$ & $86.20 \pm 1.06$ & 0.553 & 11 & $53.63 \pm 4.89$ & $42.28 \pm 3.96$ & $0.028^{\circ}$ \\
\hline Desmia non-polar & 14 & $86.68 \pm 1.54$ & $70.09 \pm 1.59$ & $<0.001^{\circ}$ & & & & \\
\hline Flexilin & 14 & $50.27 \pm 4.24$ & $47.38 \pm 6.41$ & 0.756 & 11 & $81.75 \pm 3.42$ & $65.14 \pm 4.68$ & $0.036^{\circ}$ \\
\hline Ochtodene & 14 & $59.74 \pm 4.89$ & $39.37 \pm 1.70$ & $0.002^{\circ}$ & 8 & $92.38 \pm 1.52$ & $86.00 \pm 2.11$ & $0.026^{\circ}$ \\
\hline Pachydictyol $A$ & 14 & $78.48 \pm 2.23$ & $76.32 \pm 3.43$ & 0.608 & 11 & $62.96 \pm 5.18$ & $73.14 \pm 4.04$ & 0.071 \\
\hline Udoteal & 14 & $77.65 \pm 1.97$ & $77.54 \pm 2.48$ & 0.924 & 11 & $81.93 \pm 2.28$ & $80.50 \pm 2.74$ & 0.842 \\
\hline Tydemania alcohol & & & & & 11 & $62.46 \pm 4.66$ & $41.72 \pm 6.38$ & $0.026^{\circ}$ \\
\hline Malyngamide B & 14 & $48.27 \quad 2.75$ & $63.20 \quad 4.58$ & $0.020^{\prime}$ & & & & \\
\hline
\end{tabular}




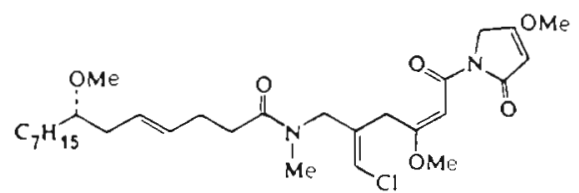

malyngamide $A$<smiles>COCC/C(=C/O)CC/C=C(\C)CC/C=C(\C)CC1CC(CO)=COO1</smiles>

chlorodesmin

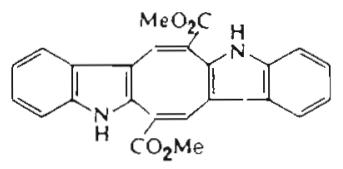

caulerpin

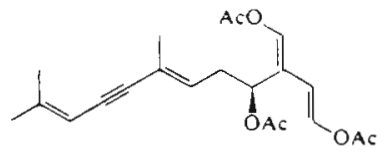

caulerpenyne<smiles>Oc1ccc(O)c(O)c1</smiles>

avrainvilleol

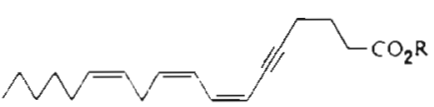

Liagora farinosa acetogen in

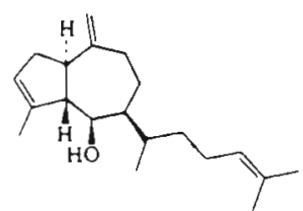

pachydictyol A<smiles>CC1(C)C(Br)CC(Cl)C(=CCBr)C1Cl</smiles>

ochtodene

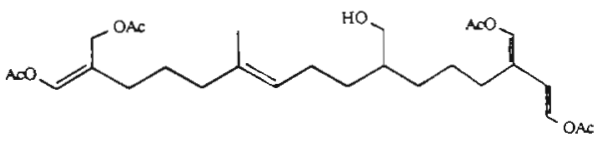

Tydemania alcohol

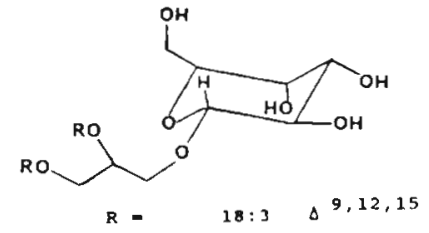

bryopsin<smiles>CC(=O)OC=C/C(=C/O)CC/C=C(\C)CCC=C(C)C</smiles>

flexilin<smiles>CC(=O)OC=C1CCC(=C(C=O)CCC=C(C)CCC=C(C)C)CO1</smiles>

Fig. 2. Summary of structures of isolated secondary metabolites used in the feeding deterrence assays. The structure of malyngamide $\mathrm{B}$ has not been reported in the literature but is closely related to malyngamide $\mathrm{A}$. Both metabolites are present in Microcoleus lyngbyaceus on Guam

the food habits of Siganus spinus and S. argenteus (Tsuda \& Bryan 1973, Bryan 1975) and other rabbitfishes (Hiatt \& Strasburg 1960, Westernhagen 1973a, b, Lundberg \& Lipkin 1979, Hay et al. in press) in the western Pacific and Red Sea. These studies have suggested that there are differences in dietary preferences among species of siganids as well as between juvenile and adult forms. For instance, Tsuda \& Bryan (1973) reported that, on Guam, Chlorodesmis fastigiata is rejected by $S$. spinus but is readily consumed by $S$. argenteus. Hay et al. (in press) also found that $S$. doliatus on the Great Barrier reef readily consumed algae coated with the major Chlorodesmis metabolite chlorodesmin.

The results of our feeding deterrence assays with Siganus argenteus are also interesting in comparison with those of field studies on Guam. In studies examining the feeding-deterrent effects of algal extracts and 
isolated metabolites in field assays (Paul 1987), both the extracts of Chlorodesmis fastigiata and the isolated metabolite chlorodesmin were significant feeding deterrents to mixed-species populations of herbivorous fishes including rabbitfishes. The extract of Halimeda macroloba was not a significant deterrent in field assays, although the isolated metabolite halimedatetraacetate was deterrent at high concentrations (Paul 1987). Halimedatrial, which occurs in relatively high concentrations in $H$. discoidea, is a more potent feeding deterrent than halimedatetraacetate (Paul \& Van Alstyne 1988). $H$. discoidea was the only Halimeda extract that showed significant deterrent activity toward S. argenteus (Table 2). Extracts of 3 Caulerpa species that contained caulerpin and caulerpenyne showed no feeding deterrent effects in field assays (Paul 1987).

Our results differ from those of Targett et al. (1986) for the parrotfish Sparisoma radians in the Caribbean and from studies of Zebrasoma flavescens on Guam (Wylie \& Paul 1988). In the study by Targett and coworkers, extracts of Halimeda incrassata and the metabolites halimedatetraacetate and caulerpenyne were all significant feeding deterrents. Also, extracts of Halimeda discoidea, Bryopsis pennata, and Dictyota spp. and the isolated metabolite pachydictyol A from Dictyota spp. were all deterrents toward Z. flavescens (Wylie \& Paul 1988) but not toward the rabbitfish. Apparently, different species of herbivorous fishes respond dissimilarly to algal secondary metabolites. Other examples of the differences among herbivorous fishes in their responses to algal secondary metabolites are presented by Paul et al. (in press). Thus, seaweed preferences of herbivorous fishes may differ markedly even between ecologically similar species.

We found that juvenile and adult Siganus argenteus also differed in their susceptibilities to seaweed chemical defenses. Several extracts and isolated metabolites that were deterrent toward the adults were not effective toward the juveniles. It is possible, however, that tank effects or interactions between juvenile fish that were tested in groups could confound the comparisons between adult and juvenile fish. Avoidance of secondary metabolites may involve a learning process, and the juveniles that we used for the assays had only limited prior exposure to seaweeds. Also since juveniles have a higher rate of metabolism per gram than adults, they may have a relatively higher motivation for feeding which makes them less easily deterred by secondary metabolites. Juveniles appeared to be more constrained by the morphology of the seaweeds.

This study provides one of a few direct tests of the hypothesis that secondary metabolites are major determinants of the food preferences of a herbivorous reef fish. Our results show that, although some algal secon- dary metabolites provide effective chemical defenses against grazing by Siganus argenteus, many species that produce secondary metabolites are not avoided. The abilities of some reef fishes to consume species of seaweeds that produce high concentrations of secondary metabolites could allow them to exploit a food source that other herbivores avoid. Information on how herbivorous fishes could physiologically overcome plant defenses is lacking, and this may prove to be a promising area for future research.

Differential responses of herbivorous fishes to algal secondary metabolites may contribute to observed differences in seaweed communities among reef-slope habitats. For example, several species of Dictyota and Caulerpa are not abundant in reef-slope habitats on Guam where herbivorous fishes are common (pers. obs.), and the secondary metabolites produced by these algae do not appear to be effective defenses toward many herbivorous fishes on Guam (Paul 1987, Wylie \& Paul 1988) including Siganus argenteus. In addition, while Asparagopsis taxiformis, Caulerpa racemosa, and Liagora farinosa, which produce secondary metabolites. are common in some reef habitats on Guam, we would predict low abundances of these algae in areas where rabbitfish are abundant, especially if more highly preferred seaweeds are not available.

Acknowledgements. We are grateful to Roy Tsuda for assistance in the identification of algae used in this study and to students Jerry Castro, Kevin Foster, Karl Kuetzing, and Irene Imanil for assistance with the assays. Critical reading by $\mathrm{C}$. Birkeland, M. Hay, K. Van Alstyne, and 3 anonymous reviewers improved earlier drafts or this manuscript. This research was supported by the University of Hawaii Sea Grant College Program (Grant No. NA85AA-D-SG072) from NOAA Office of Sea Grant, Dept of Commerce, and by a HATCH grant to S.G.N. from the University of Guam Agriculture Experiment Station (GUO42) from the cooperative state research service of the USDA. HPLC instrumentation was supported by grants from Research Corporation and the National Science Foundation (BSR-8605299) to V.J.P. This is contribution No. 276 from the University of Guam Marine Laboratory.

\section{LITERATURE CITED}

Amico, V., Orient, G., Piatelli, M., Tringali, C., Fattorusso, E., Magno, S. Mayol, L. (1978). Caulerpenyne, an unusual sesquiterpenoid from the green alga Caulerpa prolifera. Tetrahedron Lett. 1978: 3593-3596

Bryan, P. G. (1975). Food habits, functional digestive morphology, and assimilation efficiency of the rabbitfish Siganus spinus (Pisces, Siganidae) on Guam. Pacif. Sci. 29: 269-277

Burreson, B. J., Moore, R. E., Roller, P. (1975a). Haloforms in the essential oil of the red alga Asparagopsis taxiformis Tetrahedron Lett. 1975: 473-476

Burreson, B. J., Woolard, F. X., Moore, R. E. (1975b). Chondrocole $A$ and $B$, two halogenated dimethylhexahydrobenzofurans from the red alga Chondrococcus hornemanni (Mertens) Schmitz. Tetrahedron Lett. 1975: 2155-2158 
Burreson, B. J., Woolard, F. X., Moore, R. E. (1975c). Evidence for the biogenesis of halogenated myrcenes from the red alga Chondrococcus hornemanni. Chem. Lett. 1975: $1111-1114$

Cardellina II, J. H., Dalietos, D., Marner, F. J., Mynderse, J. E., Moore, R. E. (1978). Levo trans-7S, methoxy tetra dec-4enoic-acid and related amides from the manne cyanophyte Lyngya majuscula. Phytochem. 17: 2091-2096

Cardellina II, J. H., Marner, F. J., Moore, R. E. (1979). Malyngamide $A$, a novel chlorinated metabolite of the marine cyanobacteria Lyngbya majuscula. J. Am. chem. Soc. 101. $240-242$

Carpenter, R. C. (1986). Partitioning herbivory and its effects on coral reef algal communities. Ecol. Monogr 56: $343-363$

Dixon, W. J. (ed.) (1985). BMDP statistical software. Univ. of California Press, Berkeley, p. 359-387

Faulkner, D. J. (1984). Marine natural products: metabolites of marine algae and herbivorous marine molluscs. Nat. Product Rep. 1: 251-280

Faulkner, D. J. (1986). Marine natural products. Nat. Product Rep. 3: 1-33

Foster, S. A. (1987). The relative impacts of grazing by Caribbean coral reef fishes and Diadema: effects of habitat and surge. J. exp. mar. Biol. Ecol. 1.05: 1-20

Hay, M. E. (1981a). Spatial patterns of grazing intensity on a Caribbean barrier reef: herbivory and algal distribution. Aquat. Bot. 11: 97-109

Hay, M. E. (1981b). Herbivory, algal distribution, and the maintenance of between-habitat diversity on a tropical fringing reef. Am. Nat. 118:520-540

Hay, M. E. (1984a). Predictable spatial escapes from herbivory: how do these affect the evolution of herbivore resistance in tropical marine communities? Oecologia (Berl.) 64: 396-407

Hay, M. E. (1984b). Patterns of fish and urchin grazing on Caribbean coral reefs: are previous results typical? Ecology 65: 446-454

Hay, M. E., Duffy, J. E., Fenical, W. (in press) Seaweed chemical defenses: among-compound and among-herbivore variance. Proc. 6th Internat. Coral Reef Symp.

Hay, M. E., Duffy, J. E., Fenical, W., Gustafson, K. (1988b). Chemical defense in the seaweed Dictyopteris delicatula: differential effects against reef fish and amphipods. Mar Ecol. Prog. Ser. 48: 185-192

Hay, M.E., Fenical, W. (1988). Marine plant-herbivore interactions: the ecology of chemical defense. Ann. Rev. Ecol. Syst. 19: 111-145

Hay, M. E., Fenical, W., Gustafson, K. (1987). Chemical defense against diverse coral-reef herbivores. Ecology 68: $1567-1580$

Hay, M. E., Paul, V. J., Lewis, S. M., Gustafson, K., Tucker, J., Trindell, R. N. (1988a). Can tropical seaweeds reduce herbivory by growing at night? Diel patterns of growth, nitrogen content, herbivory, and chemical versus morphological defenses. Oecologia (Berl.) 75: 233-245

Hay, M. E., Renaud, P. E., Fenical, W (1988c). Large mobile versus small sedentary herbivores and their resistance to seaweed chemical defenses. Oecologia (Berl.) 75: 246-252

Hay, M. E., Taylor, P. R. (1985). Competition between herbivorous fishes and urchins on Caribbean reefs. Oecologia (Berl.) 65: 591-598

Hiatt, R. W., Strasburg, D. W. (1960). Ecological relationships of the fish fauna on coral reefs of the Marshall Islands. Ecol. Monogr. 30: 65-127

Kami, H. T., Ikehara, I. I. (1976). Notes on the annual juvenile siganid harvest in Guam. Micronesica 12: 323-325
Lewis, S. M. (1985). Herbivory on coral reefs: algal susceptibility to herbivorous fishes. Oecologia Berl. 65 : 370-375

Lewis, S. M. (1986). The role of herbivorous fishes in the organization of a Caribbean reef community. Ecol. Monogr. 56: 183-200

Lewis, S. M., Wainwright, P. C. (1985). Herbivore abundance and grazing intensity on a Caribbean coral reef. J. exp. mar. Biol. Ecol. 87: 215-228

Littler, M. M., Taylor, P. R., Littler, D. S. (1983). Algal resistance to herbivory on a Caribbean barrier reef. Coral Reets 2: $111-118$

Lundberg, B., Lipkin, Y (1979). Natural food of the herbivorous rabbitfish (Siganus spp). in the Northern Red Sea. Botanica mar. 22: 173-181

Maiti, B. C., Thomson, R. H., Mahendran, M. (1978). The structure of caulerpin, a pigment from Caulerpa algae. J. Chem. Res. (S), 1978: 126-127

McConnell, O. J., Fenical, W. (1977). Halogen chemistry of the red alga Asparagopsis. Phytochem. 16: 367-374

McConnell, O.J., Hughes, P. A., Targett, N. M., Daley, J. (1982). Effects of secondary metabolites from marine algae on feeding by the sea urchin, Lytechinus variegatus. J. chem. Ecol. 8: 1437-1453

Morrison, D. (1988). Comparing fish and urchin grazing in shallow and deeper coral reef algal communities. Ecology 69: $1367-1382$

Norris, J. N., Fenical, W. (1982). Chemical defense in tropical marine algae. In: Rutzler, K. 1., McIntyre, I. G. (eds.) The Atlantic Barrier Reef ecosystem at Carrie Bow Cay, Belize 1: structure and communities. Smithson. Contr. mar Sci. 12: $417-431$

Norris, J. N., Fenical, W. (1985). Natural products chemistry in benthic marine algae: uses in ecology and systematics. In: Littler, M. M., Littler, D. S. (eds.) Handbook of phycological methods IV: Ecological field methods. Cambridge Unıversity Press, Cambridge, p. 121-145

Paul, V. J. (1987). Feeding deterrent effects of algal natural products. Bull. mar Sci. 41. 514-522

Paul, V.J., Fenical, W. (1980). Toxic acetylene-containing lipids from the red marine alga Liagora farinosa Lamouroux. Tetrahedron Lett. 21: 3327-3330

Paul, V. J., Fenical, W (1985). New bioactive terpenoids from tropical Pacific marine algae of the family Udoteaceae (Chlorophyta). Phytochem. 24: 2239-2243

Paul, V. J., Fenical, W. (1986). Chemical defense in tropical green algae, order Caulerpales. Mar Ecol. Prog. Ser. 34: $157-169$

Paul, V. J., Hay, M. E. (1986). Seaweed susceptibility to herbivory: chemical and morphological correlates. Mar Ecol. Prog. Ser. 33: 255-264

Paul, V. J., Hay, M. E., Duffy, J. E., Fenical, W., Gustafson, K. (1987). Chemical defense in the seaweed Ochtodes secundiramea (Rhodophyta): effects of its monoterpenoid components upon diverse coral-reef herbivores. J. exp. mar. Biol. Ecol. 114: 249-260

Paul, V. J., Van Alstyne, K. (1988). Chemical defense and chemical variation in some tropical Pacific species of Halimeda (Halimedaceae; Chlorophyta). Coral Reefs 6: 263-269

Paul, V. J., Wylie, C., Sanger, H. (in press). Effects of algal chemical defenses toward different coral-reef herbivorous fishes: a preliminary study. Proc. 6th Internat. Coral Reef. Symp.

Targett, N. M., Targett, T. E., Vrolijk, N.H., Ogden, J. C. (1986). Effect of macrophyte secondary metabolites on feeding preferences of the herbivorous parrotfish Sparisoma radians. Mar. Biol. 92: 141-148 
Tsuda, R. T., Bryan, P. G. (1973). Food preference of juvenile Siganus rostratus and S. spinus in Guam. Copeia 1973: 604-606

Tsuda, R. T., Wray, F. O. (1977). Bibliography of marine benthic algae of Micronesia. Micronesica 13: 85-120

Van Alstyne, K. L., Paul, V. J. (in press). The role of secondary metabolites in marine ecological interactions. Proc. 6th Internat. Coral Reef Symp.

Wells, R. J., Barrow, K. D. (1979). Acyclic diterpenes containing three enol acetate groups from the green alga Chlorodesmis fastigiata. Experientia 35: 1544-1545

Westernhagen, H. von (1973a). A preliminary study on the

This article was submitted to the editor food preferences of Siganus concatenata (Cuvier and Valenciennes). Philipp. Scient. 10: 61-73

Westernhagen, $H$. von (1973b). The natural food of the rabbit fish Siganus oranim and S. striolata. Mar. Biol. 22: 367-370

Woolard, F. X., Moore, R. E., Roller, P. P. (1979). Halogenated acetic acids and acrylic acids from the red alga Asparagopsis taxiformis. Phytochem. 18: 617-620

Wylie, C. R., Paul, V.J. (1988). Feeding preferences of the surgeonfish Zebrasoma flavescens in relation to chemical defenses of tropical algae. Mar. Ecol. Prog. Ser. 45: 23-32

Zapata, O., McMillan, C. (1979). Phenolic acids in seagrasses. Aquat. Bot. 7: $307-317$

Manuscript first received: July 5, 1989

Revised version accepted: September 20, 1989 